\title{
Chronic Phenethylamine Hallucinogen Treatment Alters Behavioral Sensitivity to a Metabotropic Glutamate 2/3 Receptor Agonist
}

\author{
Michael A Benneyworth', Randy L Smith' and Elaine Sanders-Bush',', \\ 'Department of Pharmacology, Vanderbilt University School of Medicine, Nashville, TN, USA
}

Recent clinical studies in schizophrenic patients show that a selective agonist of group II metabotropic glutamate (mGlu) receptors has robust efficacy in treating positive and negative symptoms. Group II mGlu receptor agonists also modulate the in vivo activity of psychotomimetic drugs, reducing the ability of psychotomimetic hallucinogens to increase glutamatergic transmission. The use of mouse models provides an opportunity to investigate the dynamic action that $\mathrm{mGlu2} / 3$ receptors play in regulating the behavioral effects of hallucinogen-induced glutamatergic neurotransmission using genetic as well as pharmacological strategies. The current study sought to

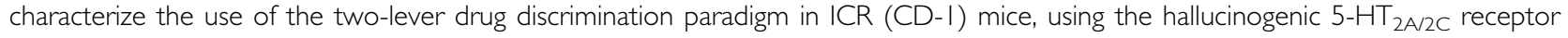
agonist (-)-2,5-dimethoxy-4-bromoamphetamine [(-)-DOB)] as a stimulus-producing drug. The (-)-DOB discriminative stimulus was dose-dependent, generalized to the hallucinogen lysergic acid diethylamide, and was potently blocked by the 5- $\mathrm{HT}_{2 \mathrm{~A}}$ receptor antagonist MI00907. However, contrary to our prediction, the hallucinogen-induced discriminative stimulus was not regulated by mGlu2/3 receptors. In a series of follow-up studies using hallucinogen-induced head twitch response and phencyclidine-induced hyperlocomotion, it was additionally discovered that the repeated dosing regimen required for discrimination training attenuated the behavioral effects of the mGlu2/3 receptor agonist LY379268. Furthermore chronic studies, using a I4 day (-)-DOB treatment, confirmed that repeated hallucinogen treatment causes a loss of behavioral activity of $\mathrm{mGlu2/3}$ receptors, likely resulting from persistent activation of mGlu2/3 receptors by a hallucinogen-induced hyperglutamatergic state.

Neuropsychopharmacology (2008) 33, 2206-2216; doi:I0.1038/sj.npp. I 301600; published online 24 October 2007

Keywords: Hallucinogen; Drug discrimination; Head twitch; Chronic treatment; 5-HT2A; mGlu2/3

\section{INTRODUCTION}

Metabotropic glutamate (mGlu) receptors are classified into three groups based on sequence homology, coupling to second messengers, and pharmacological selectivity (Conn and Pin, 1997). Group II mGlu receptors, mGlu2 and mGlu3 subtypes, couple through $\mathrm{G}_{\mathrm{i} / \mathrm{o}}$ to various effector pathways, including inhibition of adenylyl cyclase and regulation of ion channels. Through such mechanisms, presynaptic mGlu2/3 receptors may reduce glutamatergic neurotransmission in brain regions where excessive glutamatergic neurotransmission has been implicated in the pathophysiology of schizophrenia (Moghaddam and Adams, 1998; Lorrain et al, 2003). Additionally, the behavioral effects of the psychotomimetic drug ketamine in humans are disrupted by an mGlu2/3 receptor agonist (Krystal et al, 2005) and a recent phase II clinical trial shows that an mGlu2/3 receptor agonist is an effective antipsychotic

*Correspondence: Dr E Sanders-Bush, Department of Pharmacology, Vanderbilt University School of Medicine, 8I 60 MRB III, Nashville, TN 37232, USA, Tel: + 615936 1685, Fax: + 615322 442I,

E-mail: elaine.bush@vanderbilt.edu

Received 7 June 2007; revised 18 September 2007; accepted 19 September 2007 therapy, comparable to the atypical antipsychotic drug, olanzapine (Patil et al, 2007). These studies demonstrate the therapeutic potential of mGlu2/3 receptors and indicate the need to further investigate the roles of mGlu2/3 receptors in behavior and glutamatergic neurotransmission.

Psychotomimetic drugs, including dissociative anesthetics (phencyclidine (PCP) and ketamine) and hallucinogens (lysergic acid diethylamide (LSD) and psilocybin), are commonly used in experimental models of psychosis to probe the pathophysiology of schizophrenia. These drugs produce a state of intoxication that resembles the symptoms of acute schizophrenia (Vollenweider and Geyer, 2001). Additionally, human brain imaging demonstrates a common pattern of increased activity in the frontal cortex caused by psychotomimetic drugs and acute schizophrenia (Cleghorn et al, 1989; Hermle et al, 1992; Kaplan et al, 1993; Ebmeier et al, 1995; Vollenweider et al, 1997a, b), consistent with a role for hyperglutamatergic signaling in psychotic behaviors. Investigation of hallucinogenic drug action as a model of psychosis suggests that the behavioral effects of hallucinogens in humans are mediated by activation of serotonin (5-HT) subtype $2 \mathrm{~A} \quad\left(5-\mathrm{HT}_{2 \mathrm{~A}}\right)$ receptors (Vollenweider et al, 1998). Hallucinogen-induced activation of $5-\mathrm{HT}_{2 \mathrm{~A}}$ receptors increases spontaneous excitatory postsynaptic currents (EPSCs) in layer V pyramidal neurons 
of the medial prefrontal cortex (mPFC) (Aghajanian and Marek, 1997, 1999) in a manner consistent with the induction of glutamate release from presynaptic nerve terminals. Activation of mGlu2/3 receptors dramatically attenuates $5-\mathrm{HT}_{2 \mathrm{~A}}$ receptor-induced EPSCs (Marek et al, 2000), supporting the use of hallucinogens as a model for studying the regulation of hyperactive glutamatergic signaling by mGlu2/3 receptors in vivo. Consistent with this model, mGlu2/3 receptor agonists attenuate the behavioral effects of hallucinogens (Gewirtz and Marek, 2000; Klodzinska et al, 2002; Winter et al, 2004). While a range of behavioral assays have been developed to test hallucinogenic drug action in rodents, of particular interest is the two-lever drug discrimination paradigm. Drug-induced interoceptive cues serve as the stimuli that animals learn to discriminate. This assay allows an objective quantification of the interoceptive cue in laboratory animals, and correlates with the subjective effects of hallucinogens reported by humans (Appel et al, 1982; Colpaert, 1999). Drug discrimination studies in rats have presented evidence that the discriminative stimulus effects of LSD and other hallucinogens occurs via activation of the $5-\mathrm{HT}_{2 \mathrm{~A}}$ receptor (Glennon et al, 1983; Glennon et al, 1984; Titeler et al, 1988; Fiorella et al, 1995; Winter et al, 2004). The recent development of genetically-modified mouse strains provides a unique opportunity to explore the molecular basis of the hallucinogenic drug action, however only a few studies have begun to characterize the hallucinogen-induced discriminative stimulus in mice (Smith et al, 2003; Benneyworth et al, 2005; Winter et al, 2005).

The initial goal of the present study was to investigate and characterize the use of the hallucinogenic $5-\mathrm{HT}_{2 \mathrm{~A} / 2 \mathrm{C}}$ receptor agonist (-)-2,5-dimethoxy-4-bromoamphetamine [(-)-DOB] as a discriminative stimulus in ICR (CD-1) mice in order to study the physiological antagonism between 5$\mathrm{HT}_{2 \mathrm{~A}}$ and $\mathrm{mGlu} 2 / 3$ receptors. In the process of investigating the ability of mGlu2/3 receptors to modulate the (-)-DOB discriminative stimulus, it was discovered that there appeared to be a chronic effect of the repeated drug dosing in the continual discrimination training. Consistent with the observations that hallucinogens cause an in vivo increase in extracellular glutamate in the rat cerebral cortex (Scruggs et al, 2003; Muschamp et al, 2004), we hypothesized that the repeated hallucinogen treatment required for discrimination training resulted in persistent glutamatergic signaling, which chronically activated mGlu $2 / 3$ receptors resulting in desensitization and/or downregulation. As a first step at testing this hypothesis, we investigated the behavioral effect that repeated $(-)$-DOB treatment had on the efficacy of mGlu2/3 receptor agonists in additional behavioral paradigms, including the hallucinogen-induced head twitch response (HTR). This response is a stereotyped behavior known to rely on the activation of $5-\mathrm{HT}_{2 \mathrm{~A}}$ receptors by hallucinogenic drugs (Schreiber et al, 1995; Willins and Meltzer, 1997; Gonzalez-Maeso et al, 2007).

\section{MATERIALS AND METHODS}

\section{Subjects}

Subjects for experimentation were male ICR (CD-1) mice 8-10 weeks of age (Harlan, Indianapolis, IN). Mice were free fed, except during the drug discrimination experiments when the mice were maintained on a restricted diet aimed at keeping them at $\sim 80 \%$ of free-fed body weight (monitored daily); food restriction was begun 2 weeks prior to the onset of training and consisted of free access to food for $4 \mathrm{~h}$ per day Monday through Thursday (after the training session), and $a d$ lib access from Friday (after testing) until Sunday afternoon. Mice had free access to water except during the training session. All mice were maintained on a 12:12 light/ dark cycle with light onset at $0600 \mathrm{~h}$. All experiments were done in compliance with the guide for the Principles of Laboratory Animal Care (NIH publication No. 85-23, revised 1996).

\section{(-)-DOB Discrimination}

Apparatus. Training and experimentation were conducted in six commercially available mouse operant conditioning chambers (ENV 307A; Med Associates, Georgia, VT, USA), housed in a sound attenuated box. The experimental chambers were equipped with two ultra-sensitive response levers (ENV $310 \mathrm{M}$ ) and a liquid dipper (ENV $302 \mathrm{M}$ ) centered between the two levers. The equipment and experimental parameters were programmed using MED Associates software and controlled by MED Associates interface and MS-DOS compatible computers.

Training and testing procedures. Training procedures were adapted from previous studies in this laboratory (Smith et al, 2003; Benneyworth et al, 2005). Mice $(n=22)$ were trained to lever press for food reward, then discrimination training was initiated using a variable interval (VI) schedule of reinforcement that progressed from a VI $10 \mathrm{~s}$ to a VI $30 \mathrm{~s}$ schedule where it remained for the duration of the experiments.

Discrimination learning was monitored twice weekly by calculating the percent correct lever responses (number of responses on correct lever/total number of responses) during a $2.5 \mathrm{~min}$ extinction period at the beginning of the training session. Mice were initially trained on $0.3 \mathrm{mg} / \mathrm{kg}$ (-)-DOB (s.c.) vs saline. Through training day 66 , the mice as a whole had not acquired the discrimination (defined as $85 \%$ correct for both drug and saline during the $2.5 \mathrm{~min}$ extinction tests), so the dose of (-)-DOB was gradually increased to a final training dose of $0.5 \mathrm{mg} / \mathrm{kg}(-)-\mathrm{DOB}$ administered $20 \mathrm{~min}$ prior to the training session.

Experimental testing was initiated when the mice averaged $>90 \%$ correct for both (-)-DOB and saline during the twice-weekly trials. Experimental tests consisted of $5 \mathrm{~min}$ extinction sessions, which were always preceded by a minimum of four training days. Unless otherwise indicated, tests were performed using a between-subject design with each animal being tested under one treatment condition.

\section{(-)-DOB-Induced Head Twitch Response}

Mice were transferred from the colony room to the observation room and allowed to habituate for $30 \mathrm{~min}$. To assess HTR, mice were treated with $(-)$-DOB $(0.5 \mathrm{mg} / \mathrm{kg}$, s.c.) and immediately placed in a $3 \mathrm{~L}$ glass beaker and observed for $30 \mathrm{~min}$ by two observers, one of whom was blind to the treatment. HTRs were counted in $5 \mathrm{~min}$ time 
bins. Counts from the two observers were averaged. Drugnaive mice (8-10 weeks of age) were tested for the ability of LY379268 to attenuate ( - )-DOB-induced head twitches. Mice $(n=7-8)$ were treated with either LY379268 (3.0 or $10 \mathrm{mg} / \mathrm{kg}$, i.p.) or saline $10 \mathrm{~min}$ prior to (-)-DOB. HTR was also assessed in mice trained to discriminate (-)-DOB from saline. Mice were tested 48 to $72 \mathrm{~h}$ after the last (-)-DOB training session, reproducing the conditions of the discrimination tests. (-)-DOB-trained mice were divided into three groups $(n=7-8)$, receiving either LY379268 (3.0 or $10 \mathrm{mg} / \mathrm{kg}$, i.p.) or saline $10 \mathrm{~min}$ prior to $0.5 \mathrm{mg} / \mathrm{kg}(-)-\mathrm{DOB}$ (s.c.). Immediately following injection of (-)-DOB, mice were placed in a glass beaker and head twitches were counted. To assess the effects of a drug 'washout', the same groups of mice were retested 9 weeks after the last (-)-DOB training session allowing for a repeated measures comparison to the HTR data obtained during training.

\section{PCP-Induced Hyperlocomotion}

Apparatus. Open field chambers $(27 \times 27 \times 20 \mathrm{~cm}$; MED Associates, St. Albans, VT) equipped with 16 horizontal $(x$ - and $y$-axes) and 16 vertical ( $z$-axis) infrared photobeams located 1 and $5.5 \mathrm{~cm}$ above the floor of the chamber, respectively, were used to detect locomotor activity. Movements were detected as photobeam breaks and were recorded by a PC-based computer equipped with mouse activity-monitoring system software (MED Associates). The software program filtered the data to count only multiple beam-breaking movements as ambulations, and converted beam breaks into distance traveled (in $\mathrm{cm}$ ).

Blockade of PCP-induced hyperlocomtion by mGlu2/3 receptor agonist. Drug-naive mice (8-10 weeks of age) were divided into three groups $(n=8)$, to receive one of two doses of LY379268 (3.0 or $10 \mathrm{mg} / \mathrm{kg}$, i.p.) or saline. All mice were treated with PCP $(5.6 \mathrm{mg} / \mathrm{kg}$, s.c. $)$. Mice were placed in the open field chamber for a $30 \mathrm{~min}$ habituation period. At this point $(t=30 \mathrm{~min})$ the mice were injected with LY379268 or saline, followed immediately by injection of PCP and returned to the open field chamber. Locomotor activity was recorded for an additional $90 \mathrm{~min}$. Mice trained on (-)-DOB-saline discrimination were similarly tested $48 \mathrm{~h}$ after the last ( -$)$-DOB training session $(n=7-8)$.

\section{Chronic (-)-DOB Treatments}

In order to further assess the effects of repeated (-)-DOB treatments on behavioral sensitivity to mGlu2/3 receptor agonists, a more traditional chronic dosing design was employed. Mice were injected daily for 14 days with either $1.0 \mathrm{mg} / \mathrm{kg}(-)$-DOB $(n=12)$ or saline $(n=12)$. Treatments were administered (s.c.) at the same time each day (12:002:00). Forty-eight hours after the last chronic treatment, mice were pretreated with either LY379268 $(3.0 \mathrm{mg} / \mathrm{kg}$, i.p.) or saline $10 \mathrm{~min}$ prior to (-)-DOB $(0.5 \mathrm{mg} / \mathrm{kg}$, s.c.) and head twitches counted.

\section{Drugs}

Drugs were dissolved in deionized water and administered in an injection volume of $10 \mathrm{ml} / \mathrm{kg}$, except M100907 that was dissolved in a minimal volume $(0.1 \mathrm{ml})$ of $2 \%$ tartaric acid and then diluted in deionized water. LY379268, LY354740, and LY341495 were dissolved in water and $\mathrm{pH}$ was normalized with $1 \mathrm{~N} \mathrm{NaOH}$. (-)-DOB and LSD were provided by the National Institute of Drug Abuse. M100907 was a gift from Marion Merrell Dow (Cincinnati, OH). LY379268 and LY354740 were gifts from Eli Lilly and Co (Indianapolis, IN). LY341495 was purchased from Tocris Cookson (Baldwin, MO). PCP hydrochloride was purchased from Sigma-Aldrich (St. Louis, MO).

\section{Statistics}

Results are presented as mean \pm SEM. Data were compiled, plotted, and analyzed using GraphPad Prism 4.00 (GraphPad Software, Inc., San Diego, CA). Variable slope sigmoidal dose-resposne curves, with minimal (0) and maximum (100) constraints, were generated to calculate the $\mathrm{ED}_{50}$ and $\mathrm{ID}_{50}$ values. The goodness of fit $\left(R^{2}\right)$ of these nonlinear regressions was also calculated. Dose-response studies were analyzed with either a one-way or two-way analysis of variance (ANOVA). The within-subject experiment (head twitches in (-)DOB-trained mice) was analyzed with repeated measures ANOVA. Post hoc comparisons were done using the Dunnett's multiple comparison tests. All single-dose drug discrimination experiments were analyzed using an unpaired student's $t$-test. For all analyses, a $p$-value of less than 0.05 was considered to be statistically significant.

\section{RESULTS}

\section{Discrimination Training}

Initially mice were trained to discriminate $0.3 \mathrm{mg} / \mathrm{kg}(-)$ DOB from saline, and the acquisition of discrimination was followed using twice-weekly $2.5 \mathrm{~min}$ extinction sessions performed at the outset of a training session. Figure 1 illustrates the gradual acquisition of a discriminative response. Through 63 days of training the mice had failed to reach a stable discrimination above the criterion $(85 \%$ on the appropriate lever, depicted by the horizontal lines in the figure). On training day 66 the dose of (-)-DOB was increased to $0.4 \mathrm{mg} / \mathrm{kg}$, and on day 78 the dose was further increased to $0.5 \mathrm{mg} / \mathrm{kg}$. This subsequent dose resulted in the discriminative response improving well beyond the criterion, with the average nearing $95 \%$ on the appropriate lever. This high degree of discrimination was desired because it produces more reliable and reproducible responses in test sessions.

\section{Pharmacological Characterization of (-)DOB Discrimination}

Following acquisition of the discriminative response, a dose-response curve was determined with four doses of $(-)$-DOB $(0,0.125,0.25$, and $0.5 \mathrm{mg} / \mathrm{kg})$, administered 20 min prior to testing. As shown in Figure 2, (-)-DOB choice behavior (percent responding on the (-)-DOB correct lever) was dose-dependent $[\mathrm{F}(3,15)=31.81$, $p<0.0001]$, with an $\mathrm{ED}_{50}$ of $0.16 \mathrm{mg} / \mathrm{kg}\left(R^{2}=0.86\right)$. Post hoc analysis showed that both 0.25 and $0.5 \mathrm{mg} / \mathrm{kg}$ produced 


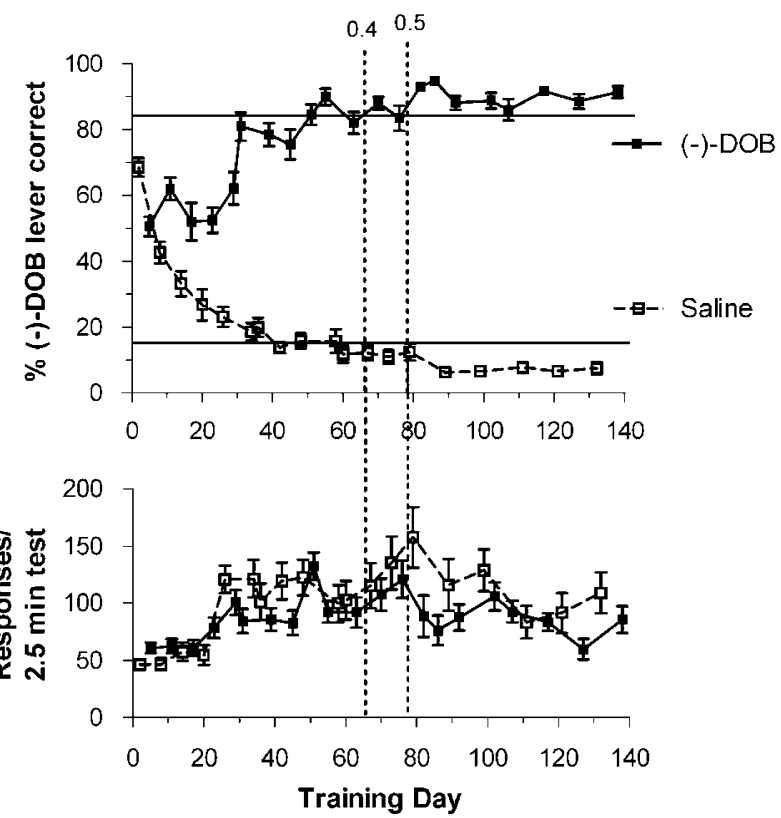

Figure I Acquisition of $(-)-D O B$ discrimination. Mice $(n=22)$ were trained to discriminate $0.5 \mathrm{mg} / \mathrm{kg}(-)$-DOB from saline on a $\mathrm{VI} 30 \mathrm{~s}$ schedule of reinforcement. Data represent mean \pm SEM choice response (upper panel) and total responses (lower panel) measured during $2.5 \mathrm{~min}$ extinction tests given twice weekly. Data are plotted as the mean percent responding on the (-)-DOB correct lever 20 min after saline or (-)-DOB treatment. Horizontal lines indicate discrimination criteria (85\% on the appropriate lever). Vertical dashed lines indicate the sessions where dose was increased to indicated dose $(\mathrm{mg} / \mathrm{kg})$.

significantly higher (-)-DOB choice response than saline treatment. Response rate did not significantly change with increasing doses of $(-)$-DOB $[\mathrm{F}(3,15)=1.51]$.

Next, the substitution of LSD for the (-)-DOB discriminative stimulus was examined. This assay tests the generalization of the interoceptive cue produced by drugs with a similar pharmacological component. LSD $(0.075,0.15$, or $0.3 \mathrm{mg} / \mathrm{kg}$, s.c.) or saline was injected $10 \mathrm{~min}$ prior to testing (Figure 2). Consistent with the observation that (-)-DOB substitutes for LSD in mice (Benneyworth et al, 2005), LSD produced a dose-dependent increase in percent responding on the (-)-DOB lever $[\mathrm{F}(3,17)=13.9, p<0.001]$, with an $\mathrm{ED}_{50}$ of $0.11 \mathrm{mg} / \mathrm{kg}\left(R^{2}=0.69\right)$. Post hoc analysis shows that, at 0.15 and $0.3 \mathrm{mg} / \mathrm{kg} \mathrm{LSD}$, the choice response was significantly different than saline treatment. At a dose of $0.3 \mathrm{mg} / \mathrm{kg} \mathrm{LSD}$, animals made $87 \pm 4 \%$ of their responses on the $(-)$-DOB lever indicating that LSD fully substituted for (-)-DOB. Response rates declined as a function of increasing doses of LSD, however, this decline in rate did not reach statistical significance $[\mathrm{F}(3,17)=1.01]$.

Further characterization of the (-)-DOB stimulus was performed by examining the role of $5-\mathrm{HT}_{2 \mathrm{~A}}$ receptor activation in the interoceptive cue. Varying doses of the 5$\mathrm{HT}_{2 \mathrm{~A}}$ receptor-selective antagonist $\mathrm{M} 100907$ (0.01, 0.03, and $0.1 \mathrm{mg} / \mathrm{kg}$ ) and saline were administered $20 \mathrm{~min}$ prior to $0.5 \mathrm{mg} / \mathrm{kg}(-)-\mathrm{DOB}$, and mice were tested $20 \mathrm{~min}$ later (Figure 3). M100907 caused a dose-dependent decrease in $(-)$-DOB lever responding $[\mathrm{F}(3,18)=119.7, p<0.0001]$, with an $\mathrm{ID}_{50}$ of $0.008 \mathrm{mg} / \mathrm{kg} \quad\left(R^{2}=0.95\right)$. Post hoc analysis indicated that all doses of M100907 significantly reduced (-)-DOB lever selection as compared to saline

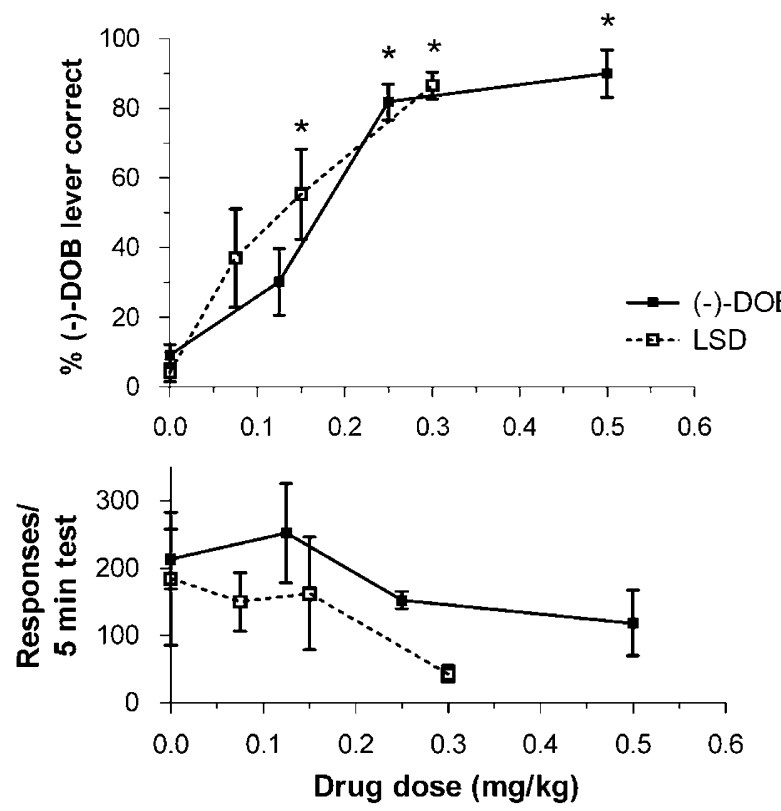

Figure 2 (-)-DOB and LSD dose-response curves. Data represent mean $\pm \operatorname{SEM}(n=4-6)$ responding on the $(-)$-DOB lever (upper panel) and total responses (lower panel) made during a 5 min extinction test as a function of varying doses of (-)-DOB or LSD. Tests were performed 20 min after (-)-DOB injection or 10 min after LSD injection. Asterisks (*) indicate groups treated with a drug dose that caused lever selection significantly different than vehicle control ( $p<0.0$ I, Dunnett).

pretreatment. A dose of $0.03 \mathrm{mg} / \mathrm{kg}$ M100907 was completely effective (response on (-)-DOB lever; $5.5 \pm 1.4 \%$ ) at antagonizing the (-)-DOB discriminative stimulus induced by a dose of $0.5 \mathrm{mg} / \mathrm{kg}(-)$-DOB. There was no significant effect of pretreatment on response rate $[\mathrm{F}(3,18)=1.02]$.

\section{Effect of mGlu2/3 Receptor Drugs on (-)-DOB Discrimination}

To explore the physiological antagonism that group II mGlu receptors are hypothesized to exert on hallucinogenic drug action, (-)-DOB was tested after pretreatment with the mGlu2/3 receptor agonists LY379268 and LY354740. Activation of mGlu2/3 receptors has been previously shown to attenuate the LSD discriminative stimulus in rats (Winter et al, 2004). Multiple doses of LY379268 (1.0, 3.0, and $10 \mathrm{mg} /$ $\mathrm{kg}$ ) and saline or LY354740 (5.0, 10, and $20 \mathrm{mg} / \mathrm{kg}$ ) and saline were administered 20 min prior to a submaximum dose of $(-)$-DOB $(0.3 \mathrm{mg} / \mathrm{kg})$ and discrimination behavior was assessed (Table 1). Neither agonist reduced choice response at any dose tested. LY379268 was tested again under varying treatment conditions, including alterations in (-)-DOB dose $(0.15$ or $0.3 \mathrm{mg} / \mathrm{kg})$, route of administration (s.c. or i.p.), and pretreatment time [0,10, or 20 min prior to $(-)$-DOB]. These experiments, summarized in Table 1 , found no difference between pretreatment with the mGlu2/3 agonist and saline. Additionally, the ability of the mGlu2/3 receptor antagonist LY341495 to potentiate the (-)-DOB discriminative stimulus was examined. In single dose (3.0) and dose-response $(0.1,0.3,1.0,3.0$, and $10 \mathrm{mg} / \mathrm{kg})$ experiments, LY341495 did not significantly alter the choice 

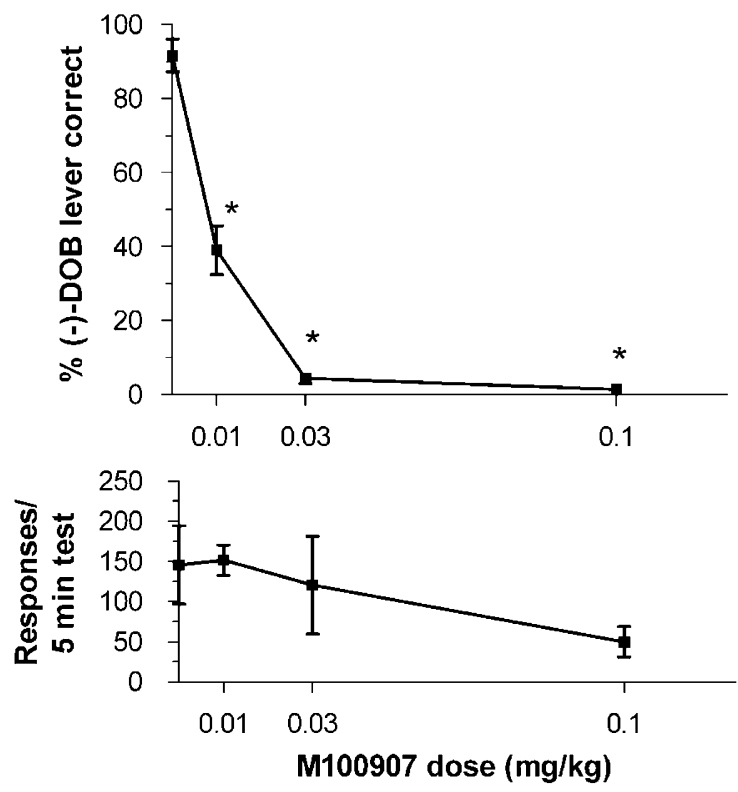

Figure 3 MI00907 dose-dependent antagonism of (-)-DOB. The ability of the $5-\mathrm{HT}_{2 \mathrm{~A}}$ receptor antagonist $\mathrm{MI} 00907$ to block the response to $(-)$-DOB $(0.5 \mathrm{mg} / \mathrm{kg})$ is shown. Data represent mean \pm SEM $(n=5-6)$ responding on the $(-)$-DOB lever (upper panel) and total responses (lower panel) made during a 5 min extinction test as a function of increasing doses of MI00907 administered $20 \mathrm{~min}$ prior to (-)-DOB (40 min prior to testing). Asterisks (*) indicate lever selection significantly different from vehicle control ( $p<0.01$, Dunnett).

of drug lever (Table 1). This complete absence of mGlu2/3 receptor regulation of the (-)-DOB discriminative stimulus was reproduced in a separate group of mice also trained on $0.5 \mathrm{mg} . \mathrm{kg}(-)$-DOB (data not shown).

\section{(-)-DOB-induced HTR in Mice Trained to Discriminate $(-)$-DOB}

The (-)-DOB-induced HTR was examined in the mice trained to discriminate (-)-DOB from saline to determine whether the repeated drug treatments of the discrimination training were having a more generalized effect on the ability of mGlu2/3 receptors to regulate the behavioral effects of hallucinogens, as compared to drug-naive controls. (-)DOB-trained mice were tested for HTR 48-72 $\mathrm{h}$ after the last $(-)$-DOB training session to reproduce the timing that was used in the discrimination tests. (-)-DOB-trained and drug-naive mice were treated with the mGlu2/3 receptor agonist LY379268 (3.0 or $10 \mathrm{mg} / \mathrm{kg}$, i.p.) or saline $10 \mathrm{~min}$ prior to (-)-DOB $(0.5 \mathrm{mg} / \mathrm{kg}$, s.c.). The number of head twitches was expressed as a percent of the HTR observed for the saline pretreatment in each respective group of mice (Figure 4). A one-way ANOVA showed that LY379268 reduced the $(-)$-DOB-induced $\operatorname{HTR}[\mathrm{F}(2,15)=8.27$, $p<0.01]$ in the drug-naive mice. Post hoc analysis indicated that both doses of LY379268 (3.0 and $10 \mathrm{mg} / \mathrm{kg})$ were significantly different than saline pretreatment. However, the (-)-DOB-trained mice were insensitive to the effects of

Table I Summary of Multiple Experiments with mGlu2/3 Receptor Agonists and an Antagonist

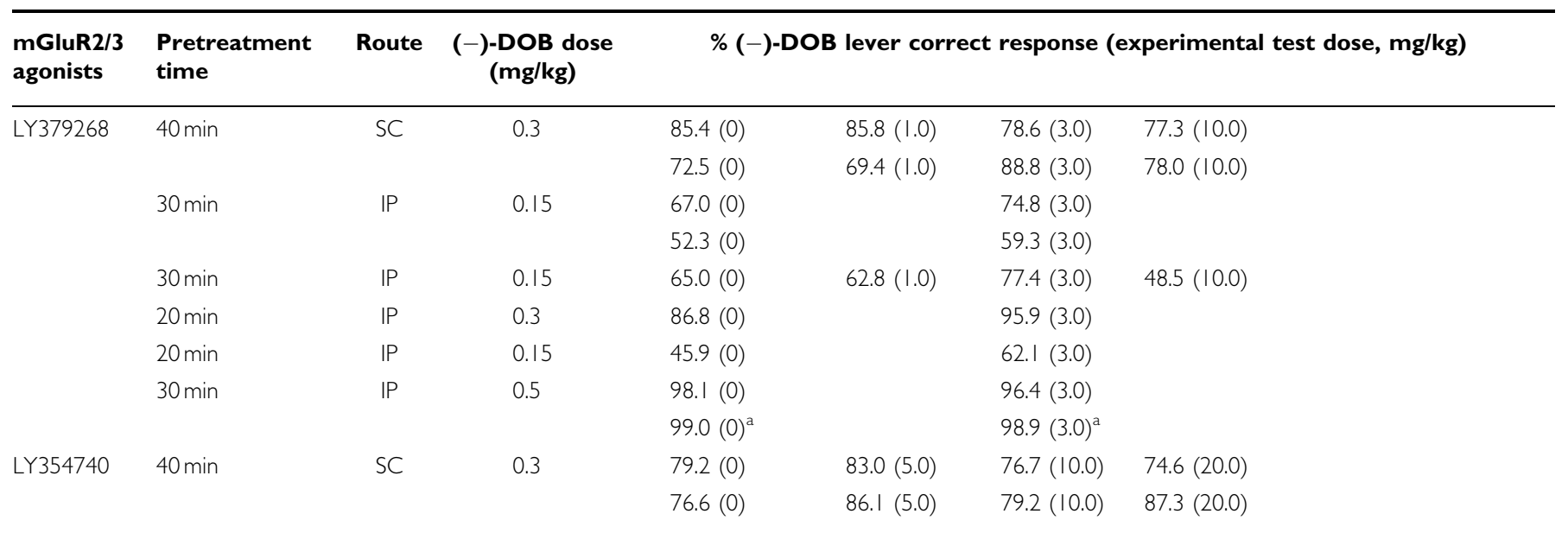

\begin{tabular}{|c|c|c|c|c|c|c|c|c|c|}
\hline \multicolumn{10}{|c|}{$\begin{array}{l}\text { mGluR2/3 } \\
\text { antagonist }\end{array}$} \\
\hline LY34I495 & $40 \mathrm{~min}$ & $\mathrm{IP}$ & 0.15 & $67.0(0)$ & $54.0(0.1)$ & $48.3(0.3)$ & $75.7(1.0)$ & $49.7(3.0)$ & $42.7(10.0)$ \\
\hline & & & & $62.0(0)$ & & & & $41.0(3.0)$ & \\
\hline
\end{tabular}

This table summarizes the various experiments performed to examine the effects of mGlu2/3 receptor agonists (LY379268 or LY354740) or an antagonist (LY34|495) on (-)-DOB discrimination. Single $(n=8-10)$ and multiple $(n=4-6)$ dose experiments were performed. Pretreatment time represents total time before test, including $20 \mathrm{~min}$ after (-)-DOB injection. Data represent the mean response on the (-)-DOB lever. No significant effect on choice response was found with any pretreatment.

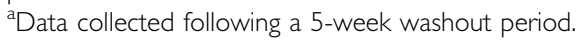




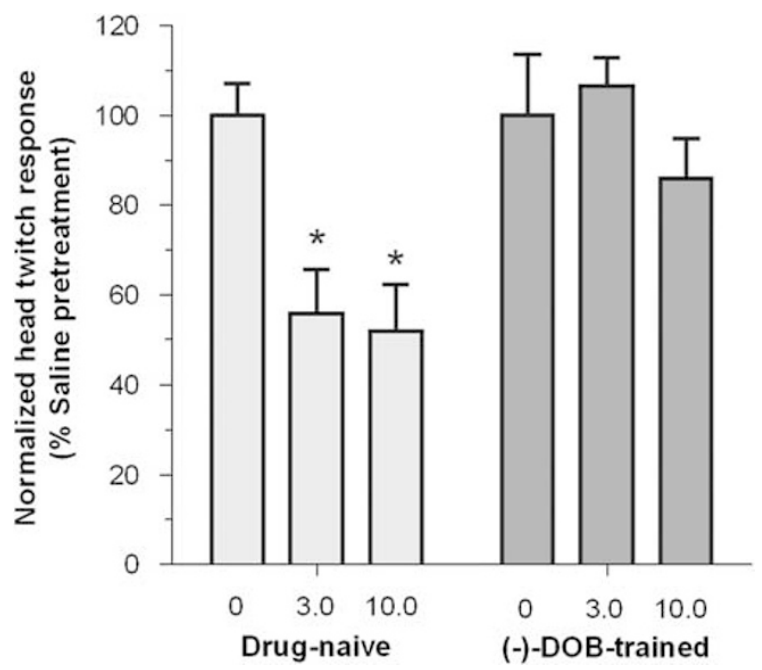

Figure 4 Failure of LY379268 to block (-)-DOB head twitch response (HTR) in mice trained to discriminate (-)DOB. Blockade of (-)-DOBinduced HTR by LY379268 (0, 3.0 or $10.0 \mathrm{mg} / \mathrm{kg}$ ) was compared between drug-naive and (-)-DOB discrimination-trained mice (tested $48-72 \mathrm{~h}$ after last (-)-DOB treatment). Data depict the HTR normalized to percent maximum HTR (saline pretreatment for each group of mice). Mice $(n=6-$ 8) were pretreated with the $\mathrm{mGlu2} / 3$ receptor agonist LY379268 (3.0 or $10.0 \mathrm{mg} / \mathrm{kg})$ or saline $10 \mathrm{~min}$ prior to (-)-DOB $(0.5 \mathrm{mg} / \mathrm{kg}$, s.c.). Total HTR for mice treated with saline/(-)-DOB was $61.2 \pm 4.4$ for drug-naive mice and $48.9 \pm 6.7$ for (-)-DOB-trained mice. Asterisks (*) indicate significant attenuation of response as compared to corresponding saline pretreatment $(p<0.05$, Dunnett)

LY379268, displaying no attenuation of the (-)-DOBinduced HTR $\mathrm{F}(2,19)=0.92]$.

\section{PCP-Induced Hyperlocomotion in Mice Trained to Discriminate (-)-DOB}

Further examination of the effects of the discrimination training drug regimen on behavioral sensitivity to activation of mGlu2/3 receptors involved testing the hyperlocomotive action of PCP. Previous work has demonstrated the ability of mGlu2/3 receptor activation to attenuate PCP-induced hyperlocomotion (Moghaddam and Adams, 1998; Cartmell et al, 1999; Galici et al, 2005). Two doses of LY379268 (3.0 and $10 \mathrm{mg} / \mathrm{kg}$ ) and saline were tested in combination with PCP $(5.6 \mathrm{mg} / \mathrm{kg})$ in drug-naive and (-)-DOB-trained mice. Drugs were administered at $t=30 \mathrm{~min}$, following a $30 \mathrm{~min}$ habituation period. In drug-naive mice, both doses of LY379268 reduced PCP-induced locomotor activity. As illustrated in Figure 5a, PCP rapidly induces hyperlocomotion, while the blockade by LY379268 does not become apparent until $20 \mathrm{~min}$ after administration $(t=50 \mathrm{~min})$. In Figure $5 \mathrm{~b}, \mathrm{PCP}$-induced activity, from time of injection $(t=30)$ to the end of the test $(t=120)$, was summated and analyzed by one-way ANOVA, demonstrating a dosedependent attenuation of activity $[\mathrm{F}(2,21)=11.1$, $p<0.001]$. Post hoc analysis showed that both 3.0 and $10 \mathrm{mg} / \mathrm{kg}$ LY379268 treatments were significantly different than saline. This same experiment was subsequently performed on mice trained to discriminate (-)-DOB, with testing performed $48 \mathrm{~h}$ after the last (-)-DOB training session (Figure 5c). Analysis of cumulative PCP-induced activity (Figure $5 \mathrm{~d}$ ) demonstrated that although there was a significant effect of LY379268 cotreatment $[F(2,19)=11.2$, $p<0.001$ ], only the $10 \mathrm{mg} / \mathrm{kg}$ dose of LY379268 resulted in a significant decrease relative to saline treatment.

\section{Effect of Washout Period on LY37968 Pretreatment in (-)-DOB-Induced Behaviors}

Taking advantage of the persistent nature of the drug discrimination response, the potential effect of the drug treatment regimen involved in the discrimination training on sensitivity to mGlu2/3 receptor activation was further examined by testing the discriminative response after a 5 week drug 'washout' period during which time training was stopped and the mice were drug-free. We reasoned that if the chronic (-)-DOB dosing causes a desensitization/ downregulation of mGlu2/3 receptors with consequent inability of mGlu2/3 receptor agonists to modulate the (-)-DOB stimulus, the activity of the mGlu2/3 agonist LY379268 might be revealed following a drug washout period. Prior to the washout period, saline and LY379268 $(3.0 \mathrm{mg} / \mathrm{kg})$, administered $10 \mathrm{~min}$ prior to $(-)-\mathrm{DOB}(0.5 \mathrm{mg} / \mathrm{kg})$, were tested in reinforced test sessions; after the drug washout period, the mice were tested again. No attenuation of choice response by LY379268 was observed either during training or after drug washout (Table 1).

The ability of LY379268 to attenuate the (-)-DOBinduced HTR was also examined in the (-)-DOB-trained mice following the 9 week drug-washout period, to investigate whether cessation of the drug treatments associated with the training regimen would restore sensitivity to the mGlu2/3 receptor agonist in a different behavioral paradigm. Mice received the same pretreatment during training, LY379268 (3.0 or $10 \mathrm{mg} / \mathrm{kg}$ ) or saline, and after washout, allowing for within subject comparison of the effect of the drug washout period (Figure 6). HTR data were subsequently normalized within each experiment to the percent maximum response (defined as the corresponding saline pretreatment group). Data shown for 'during training' are the same as depicted in Figure 4 as '(-)-DOBtrained'. As illustrated in Figure 6, LY379268 significantly attenuated the (-)-DOB-induced HTR in the 'after washout' group, with one-way ANOVA of the 'after washout' data indicating that there was a significant effect of pretreatment $[\mathrm{F}(2,16)=4.44, p<0.05]$, Post hoc analysis demonstrated that $10.0 \mathrm{mg} / \mathrm{kg}$ of LY379268 produced a significant attenuation of HTR compared to saline pretreatment $(p<0.05$, Dunnett). Additionally, a two-way ANOVA demonstrated that there was a significant main effect of drug washout period $[\mathrm{F}(1,16)=6.83, p<0.05]$.

\section{Chronic (-)-DOB Dosing Eliminates Attenuation of (-)-DOB-Induced HTR by an mGlu2/3 Receptor Agonist}

Having observed that the discrimination training regimen abolishes the ability of an mGlu2/3 receptor agonist to attenuate the HTR, an effect that was reversed by the drug washout period, it was hypothesized that the repeated (-)DOB dosing causes a functional desensitization of mGlu2/3 receptors. This was tested by chronic daily injection with $(-)$-DOB in a separate group of mice. Mice were treated daily with either (-)-DOB $(1.0 \mathrm{mg} / \mathrm{kg}$, s.c.) or saline for 14 days; $48 \mathrm{~h}$ later, either LY379268 (3.0 mg/kg, i.p.) or saline 

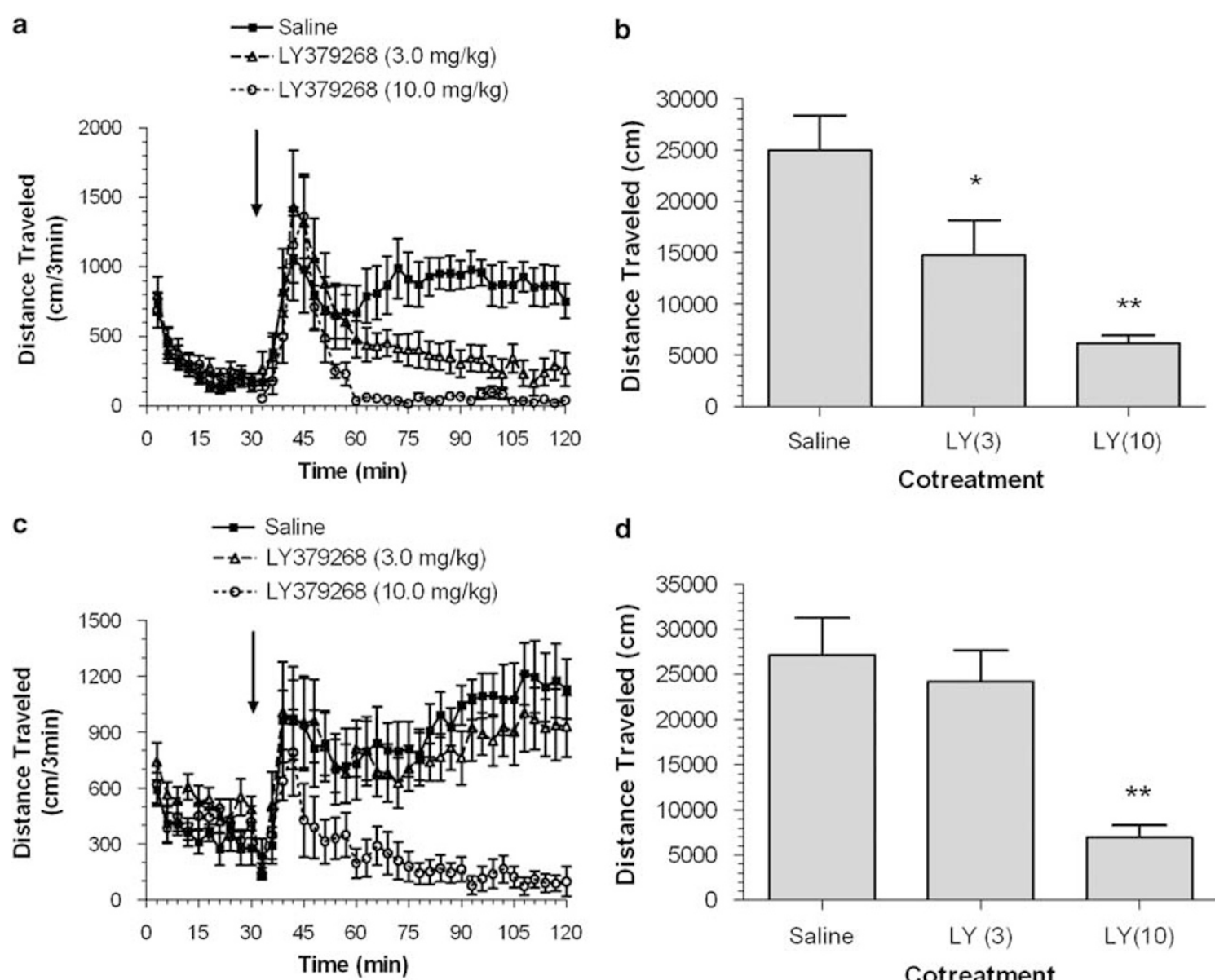

d

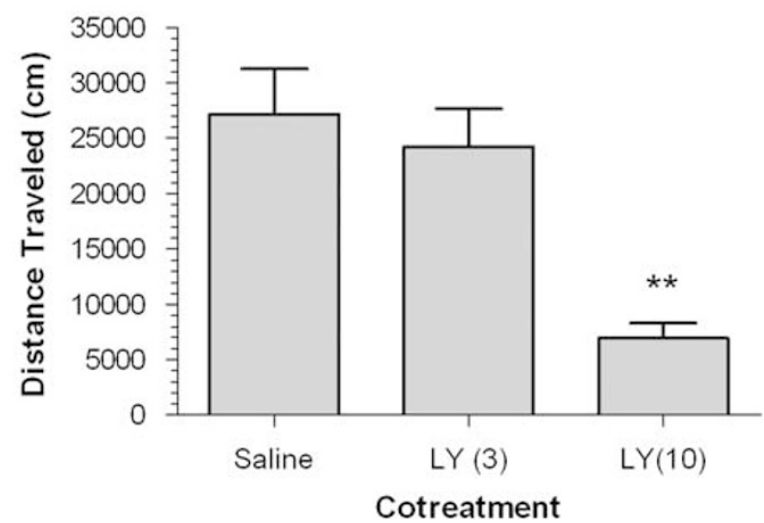

Figure 5 Time course and dose-response of LY379268-mediated blockade of PCP-induced hyperlocomotion in drug-naive and (-)-DOB-trained mice. Drug-naive (panels a and b) and (-)-DOB discrimination-trained mice (panels c and d) were administered LY379268 (3.0 or $10.0 \mathrm{mg} / \mathrm{kg}$ ) or saline followed by an injection of PCP $(5.6 \mathrm{mg} / \mathrm{kg})$ at $t=30(n=6-8$ per dose). Time of injections is indicated by the arrows $(\downarrow)$. In panels a and $\mathrm{c}$, the time course of locomotion is depicted, measured in 3 min blocks. Panels $b$ and d illustrate total PCP-induced locomotion, a summation of total distance traveled from $t=30$ to $t=120 \mathrm{~min}$. Asterisks (*) indicate a significant difference from saline treatment ( ${ }^{*} p<0.05$; $* * p<0.01$, Dunnett).

was administered $10 \mathrm{~min}$ prior to (-)-DOB $(0.5 \mathrm{mg} / \mathrm{kg}$, s.c.), and head twitches recorded for $30 \mathrm{~min}$ (Figure 7). In spite of the fact that the data appear to indicate that LY379268 effectively attenuates the (-)-DOB-induced HTR in the chronic saline mice but not the chronic (-)-DOB, a two-way ANOVA demonstrated that there was neither a main effect of either the chronic treatment $[\mathrm{F}(1,20)=2.65, p=0.42]$ or the LY379269 pretreatment $[\mathrm{F}(1,20)=14.47, p=0.066]$, nor the interaction of the two $[\mathrm{F}(1,20)=6.40, p=0.21]$. This was very surprising given the fact that the magnitude of the apparent effect of LY379268 in the chronic saline mice is similar to that observed in the drug-naive mice (Figure 4), and in the (-)-DOB-trained mice after the washout period (Figure 6). Given this observation, and the prior evidence of a chronic treatment effect, we analyzed the chronic (-)DOB mice separately to test the specific hypothesis that the chronic (-)-DOB treatment eliminated the ability of LY379268 to attenuate the (-)-DOB-induced HTR. This exploratory investigation supported our hypothesis, showing that LY379268 had no effect in the mice that had been chronically treated with (-)-DOB $(p=0.36, t$-test with Welch's correction). Interestingly, the (-)-DOB-induced HTR does not appear to be changed by the chronic (-)DOB treatment $(55.0 \pm 3.7$ vs $58.4 \pm 5.7$, saline control for chronic (-)-DOB vs chronic saline), suggesting that tolerance to (-)-DOB does not occur. In contrast, the (-)-DOB-trained mice (Figure 6) seemed to exhibit some degree of tolerance to (-)-DOB, as observed by a maximal HTR that was appeared to be reduced during training relative to the response after a 9-week washout, suggesting that intermittent, prolonged dosing is capable of causing some degree of tolerance.

\section{DISCUSSION}

Growing evidence suggests a link between hallucinogen activation of $5-\mathrm{HT}_{2 \mathrm{~A}}$ receptors and glutamate release. In addition to the activation of excitatory neurotransmission in brain slices (for review see Aghajanian and Marek, 2000), in vivo neurochemical experiments and ex vivo evaluation of hallucinogen-induced immediate early gene expression support the activation of glutamatergic signaling by hallucinogens (Scruggs et al, 2000, 2003; Zhai et al, 2003; Pei et al, 2004; Muschamp et al, 2004). Consistent with this model, group II mGlu receptor agonists have been reported to attenuate the behavioral effects of hallucinogens (Gewirtz and Marek, 2000; Klodzinska et al, 2002; Winter et al, 2004). 


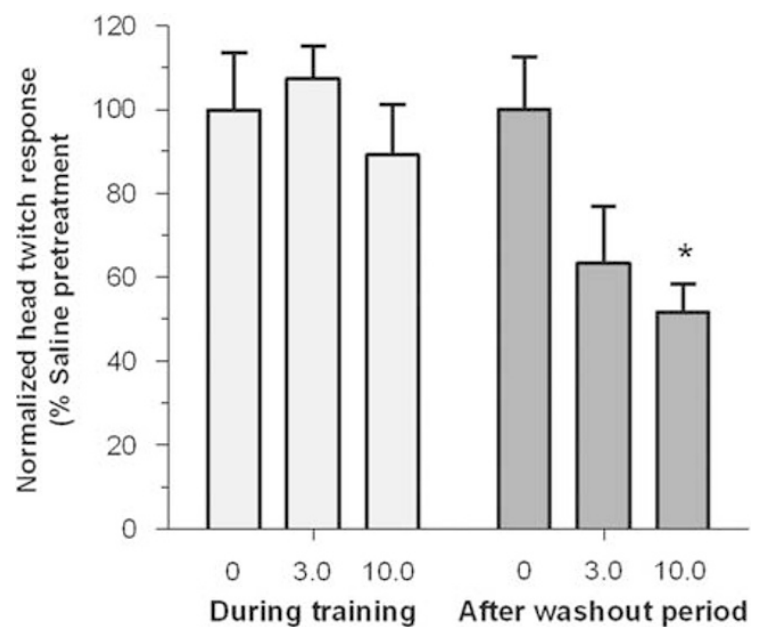

Figure 6 Effect of drug washout period on responsiveness to the LY379268-mediated blockade of (-)-DOB head twitch response (HTR) in mice trained to discriminate (-)-DOB. Blockade of $(-)$-DOB HTR by LY379268 (0, 3.0 or $10.0 \mathrm{mg} / \mathrm{kg})$ was tested twice in (-)-DOB discrimination-trained mice, once during training $(48-72 \mathrm{~h}$ after last $(-)$ $\mathrm{DOB}$ treatment) and then again after a 9 week washout period. Mice were given the same pretreatment in each test session $(n=5-8)$. Mice were pretreated with the mGlu2/3 receptor agonist LY379268 $(3.0$ or $10.0 \mathrm{mg} /$ $\mathrm{kg}$ ) or saline 10 min prior to (-)-DOB. Data depict the HTR normalized to percent maximum HTR (saline pretreatment for individual test). Total HTR following saline/(-)-DOB treatment was $48.9 \pm 6.7$ for mice during training and $79.3 \pm 10.0$ for mice after the washout period. Asterisks (*) indicate significant decrease relative to saline pretreatment $(p<0.05$, Dunnett).

Since few pharmacological tools are available to differentiate the individual group II mGlu receptor subtypes, our goal was to establish the drug discrimination paradigm in mice to model the physiological interaction between $5 \mathrm{HT}_{2 \mathrm{~A}}$ and mGlu2/3 receptors for further studies with genetically modified mice that express a single group II mGlu receptor subtype. Herein we report that the hallucinogenic drug (-)DOB produces a robust and reliable discriminative stimulus with pharmacological characteristics that agree with another hallucinogenic $5-\mathrm{HT}_{2 \mathrm{~A}}$ receptor agonist, $( \pm)$-DOI (Smith et al, 2003). Additionally, the temporal profile of the (-)-DOB stimulus (data not shown) is similar to that obtained for the substitution of (-)-DOB for LSD (Benneyworth $e$ e al, 2005), with a maximal effect occurring within 30 and waning by $135 \mathrm{~min}$ post injection. There are, however, significant dose-related differences, with (-)-DOB discrimination showing greater sensitivity to both agonist substitution and antagonist blockade than was found for $( \pm)$-DOI. These differences likely reflect multiple factors, including inherent differences between $(-)$-DOB and $( \pm)$ DOI as discriminative stimuli and differences in mice strains used in these studies (C57Bl6 vs ICR). Regardless, the current paradigm in which mice are trained to discriminate (-)-DOB was expected to be highly sensitive to potentially subtle changes mediated by a physiological interaction between $5-\mathrm{HT}_{2 \mathrm{~A}}$ receptors and mGlu receptors.

Based on the extensive evidence that hallucinogens promote excitatory neurotransmission in MPFC via 5$\mathrm{HT}_{2 \mathrm{~A}}$ receptor activation (Aghajanian and Marek, 2000; Benneyworth et al, 2007) combined with recent evidence that a hallucinogen discriminative cue depends on $5-\mathrm{HT}_{2 \mathrm{~A}}$ receptor activation within frontal cortex in rats (Gresch
Pretreatment

Saline

LY379268

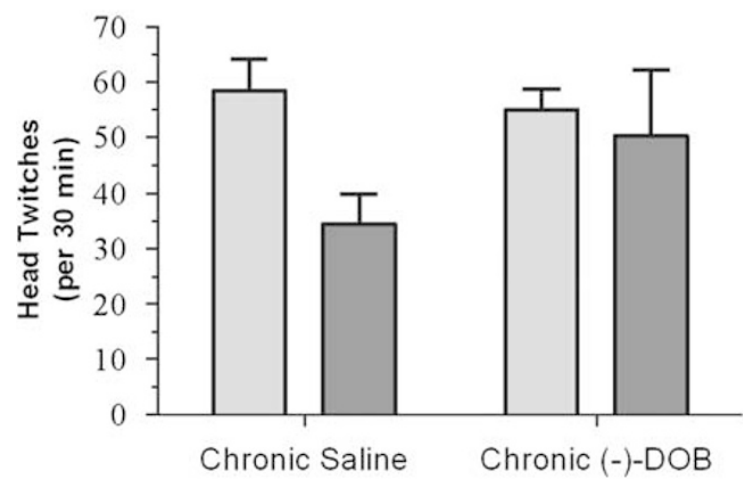

Figure 7 Effect of chronic (-)-DOB treatment on ability of the $\mathrm{mGlu2} / 3$ receptor agonist LY379268 to attenuate (-)-DOB-induced head twitch response (HTR). Mice were chronically treated (daily for 14 days) with either saline or (-)-DOB (I.0 mg/kg, s.c.). Subsequently, $48 \mathrm{~h}$ after last chronic treatment, mice $(n=6)$ were treated with either LY379268 ( $3.0 \mathrm{mg} / \mathrm{kg}$, i.p.) or saline $10 \mathrm{~min}$ prior to (-)-DOB ( $0.5 \mathrm{mg} / \mathrm{kg}$, s.c.). Data depict the (-)-DOB-induced HTR obtained in a $30 \mathrm{~min}$ session immediately following (-)-DOB treatment. There was no difference in total HTR following (-)-DOB treatment between mice chronically treated with saline or (-)-DOB.

et al, 2007), we predicted that hallucinogen discrimination would serve as a model of alterations in glutamate neurotransmission and the regulation by mGlu2/3 receptors. Contrary to these predictions and previous work by Winter et al (2004), the (-)-DOB discriminative stimulus, a $5-\mathrm{HT}_{2 \mathrm{~A}}$ receptor-mediated behavior, is not modulated by compounds acting at mGlu $2 / 3$ receptors. A wide range of mGlu2/3 receptor agonist and antagonist doses tested at multiple times fail to alter the discriminative stimulus effect of (-)-DOB. Winter et al (2004) found that in rats the LSD discriminative stimulus was subtly potentiated by an mGlu2/3 antagonist and attenuated by an mGlu2/3 agonist. However, several experimental variables differ between that work and the present study. First, and possibly the most likely causative factor is the difference in species, with the prior study being conducted in rats. While discriminative behavior is qualitatively similar between rats and mice, there could exist significant differences between the neuroanatomical substrates that underlie this task. Second, the training drug used in the prior study was LSD while (-)DOB is used here; despite the fact that these drugs were shown to substitute for each other in this and previous work (Benneyworth et al, 2005), the fact remains that their pharmacological properties are not identical. Last, the discrimination training protocol is dissimilar with Winter et al training on a fixed ratio schedule of reinforcement, while in the present study a variable interval schedule of reinforcement is used. We expected that the graded response nature of the variable interval schedule would be more conducive to subtle manipulation.

The negative findings with the mGlu2/3 agonists and antagonist suggest that the hallucinogen-induced stimulus in mice might not involve the activation of glutamatergic neuronal terminals in the mPFC. However, the drug 
discrimination paradigm requires repeated drug dosing for initial training of mice and continual retraining to maintain a consistent response. The possible chronic effects of repeated dosing, an unavoidable confound in drug discrimination, have been extensively examined with regard to training drug sensitivity and competitive pharmacological interactions. The present study probed deeper into a physiological interaction between two distinct receptor populations, and revealed that chronic hallucinogenic drug treatment elicits neuroadaptation at a secondary target. To test for potential desensitization of $\mathrm{mGlu} 2 / 3$ receptors by the repeated $(-)-D O B$ treatment in the discrimination paradigm, we compared the ability of an mGlu2/3 receptor agonist to modulate (-)-DOB-induced HTR and PCPinduced hyperlocomotion in drug-naive $v s$ mice trained in the drug discrimination paradigm. The group II mGlu receptor agonist LY379268 produces a dose-dependent blockade in both of these behaviors in drug-naive mice, in agreement with previous studies (Klodzinska et al, 2002; Galici et al, 2005). Conversely, the behavioral actions of LY379268 are blunted in mice trained to discriminate (-)DOB from saline, with a complete lack of attenuation of the (-)-DOB-induced HTR and a reduced potency to block PCP-induced hyperlocomotion. We concluded that a persistent hyperglutamatergic state caused by repeated dosing in the (-)-DOB drug discrimination training (twice weekly for many months) produces sufficient activation of mGlu2/3 receptors to elicit desensitization and/or downregulation of these receptors. Our finding that this functional deficit is also evident in the PCP hyperlocomotion test intimates a broad consequence and raises questions about the neurological and behavioral consequences of chronic hallucinogen abuse.

The functional desensitization to mGlu2/3 receptor agonists observed in these studies is likely maintained by continual drug administration and therefore could potentially be alleviated by the cessation of drug treatment. This question of reversibility was evaluated by retesting the trained mice following a prolonged 'washout' period, during which no discrimination training and related (-)-DOB treatment was performed. A recovery of the LY379268induced blockade of (-)-DOB HTR occurs following the washout period, supporting the argument that the drug treatment regimen of the discrimination training results in reversible changes in mGlu2/3 receptor activity. However, (-)-DOB discrimination remains unaffected by LY379268 even after the washout period. These behaviors, one an operant response and the other, a simple reflex, likely reflect distinct neuroanatomical circuitry, which may be differentially regulated by mGlu2/3 receptors. Such a dichotomy has previously been observed in our laboratory (Benneyworth et al, 2007), as well as others (Zhai et al, 2003), showing that hallucinogen-induced immediate early gene expression is regulated by $\mathrm{mGlu} 2 / 3$ receptors in the $\mathrm{mPFC}$, but not the somatosensory cortex. These experiments may also suggest that these two commonly studied behavioral assays are perhaps modeling distinct aspects of the range of psychological effects of hallucinogens. Alternatively, over the course of training, tolerance may have developed to the discriminative stimulus effects of (-)-DOB but gone undetected because the animals were still able to discriminate the drug from the nondrug state to the criterion of
$85 \%$. If tolerance had developed during training, a 'washout' period would be predicted to shift the (-)-DOB doseresponse curve to the left making antagonism of the training dose of (-)-DOB difficult to demonstrate. An additional confound is the difference in the length of the washout period used for the discrimination and the HTR studies. While 5 weeks is conventionally regarded as a long period of time for a mouse, it is entirely conceivable that neuroadaptive changes induced by chronic (-)-DOB required a longer period of time to recover.

In a more traditional chronic drug-dosing paradigm, we show that pretreatment with (-)-DOB for 14 days completely eliminated the mGlu2/3 receptor-mediated attenuation of HTR, as demonstrated by the selective analysis of the chronic (-)-DOB-treated mice. Caution should be taken, since the results of this experiment are not as robust as was expected, in that the two-way ANOVA did not show significance. However, the results of this experiment are consistent with the earlier finding in mice trained to discriminate (-)-DOB from saline, providing a more succinct chronic drug treatment regimen for future studies of the molecular and cellular consequences of chronic hallucinogen treatment on glutamatergic neurotransmission. It is interesting to consider that the apparent hyperglutamatergic state produced by chronic hallucinogen administration may persist for days after cessation of dosing, providing a drug-free model of the hyperglutamatergic state of psychosis. Such an effect might be analogous to studies that have examined the effects of chronic administration of the dissociative anesthetic and psychotomimetic drug, PCP (Javitt et al, 2004; Lindahl and Keifer, 2004; Rujescu et al, 2006; Dunn and Killcross, 2006; AbdulMonim et al, 2006; Abdul-Monim et al, 2007). These studies with chronically administered PCP evaluated various cellular and behavioral changes that were hypothesized to be related to persistent hyperglutamatergic signaling and chronic schizophrenia. None, however, examined mGlu2/3 receptor sensitivity. An additional study in rats by $\mathrm{Xi}$ et al (2002) showed that withdrawal from chronic cocaine, which in humans produces a psychotic state, causes reduced functioning of $\mathrm{mGlu} 2 / 3$ receptors, attributed to persistent glutamatergic signaling. Closer examination of how three pharmacologically distinct drug classes (hallucinogens, dissociative anesthetics, and psychostimulants) seem to converge on hyperglutamatergic signaling when studied in chronic experiments might lend greater understanding to the pathophysiology of schizophrenia, a disease of unknown and likely diverse etiology.

In conclusion, the current studies provide evidence for a dynamic relationship between $5-\mathrm{HT}_{2 \mathrm{~A}}$ and mGlu2/3 receptors. The reciprocal nature of this interaction is suggested by a recent study showing that a group II mGlu agonist, LY354740, protects against downregulation of $5-\mathrm{HT}_{2 \mathrm{~A}}$ receptors induced by chronic $( \pm)$-DOI treatment (Marek et al, 2006). In addition to pointing out the need for a broader scope when investigating the interaction between 5 $\mathrm{HT}_{2 \mathrm{~A}}$ and mGlu2/3 receptors, these experiments also have important implications for the targeting of mGlu2/3 receptors for development of new antipsychotic drugs. Furthermore, defining the mechanism of the altered sensitivity of $\mathrm{mGlu} 2 / 3$ receptor activity in the hyperglutamatergic state induced by repeated administration of 
psychotomimetic drugs may reveal novel strategies for modulating glutamatergic signaling and alleviating the psychotic symptoms of schizophrenia.

\section{ACKNOWLEDGEMENTS}

We thank Ms Kathleen Patterson for her skillful technical assistance in the completion of this research. The testing facilities, for drug discrimination and PCP hyperlocomotion studies, were provided by the Vanderbilt Murine Neurobehavioral Core. This work was supported in part by a grant from NIDA/NIH to E. Sanders-Bush (DA05181).

\section{DISCLOSURE/CONFLICT OF INTEREST}

The authors declare that no support or compensation has been received for this research, nor are there any personal financial holdings, that could be perceived as constituting a potential conflict of interest.

\section{REFERENCES}

Abdul-Monim Z, Neill J, Reynolds G (2007). Sub-chronic psychotomimetic phencyclidine induces deficits in reversal learning and alteration in parvalbumin-immunoreactive expression in the rat. J Psychopharm 21: 198-205.

Abdul-Monim Z, Reynolds G, Neill J (2006). The effect of atypical and classical antipsychotics on sub-chronic PCP-induced cognitive deficits in a reversal-learning paradigm. Behav Brain Res 169: 263-273.

Aghajanian GK, Marek GJ (1997). Serotonin induces excitatory postsynaptic potentials in apical dendrites of neocortical pyramidal cells. Neuropharmacology 36: 589-599.

Aghajanian GK, Marek GJ (1999). Serotonin, via $5 \mathrm{HT}_{2 \mathrm{~A}}$ receptors, increases EPSCs in layer V pyramidal cells of prefrontal cortex by an asynchronous mode of glutamate release. Brain Res $\mathbf{8 2 5}$ : 161-171.

Aghajanian GK, Marek GJ (2000). Serotonin model of schizophrenia: emerging role of glutamate mechanisms. Brain Res Rev 31: 302-312.

Appel J, White F, Holohean A (1982). Analyzing mechanism(s) of hallucinogenic drug action with drug discrimination procedures. Neurosci Behav Rev 6: 529-536.

Benneyworth MA, Smith RL, Barrett RJ, Sanders-Bush E (2005). Complex discriminative stimulus properties of (+)lysergic acid diethylamide (LSD) in C57Bl/6J mice. Psychopharmacology (Berl) 179: 854-862.

Benneyworth MA, Xiang Z, Smith RL, Garcia EE, Conn PJ, Sanders-Bush E (2007). A selective positive allosteric modulator of metabotropic glutamate receptor subtype 2 blocks a hallucinogenic drug model of psychosis. Mol Pharm 72: 477-484.

Cartmell J, Monn JA, Schoepp DD (1999). The metabotropic glutamate $2 / 3$ receptor agonists LY354740 and LY379268 selectively attenuate phencyclidine versus d-amphetamine motor behaviors in rats. J Pharmacol Exp Ther 291: 161-170.

Cleghorn JM, Garnett ES, Nahmias C, Firnau G, Brown GM, Kaplan $\mathrm{R}$ et al (1989). Increased frontal and reduced parietal glucose metabolism in acute untreated schizophrenia. Psychiatry Res 28: 119-133.

Colpaert FC (1999). Drug discrimination in neurobiology. Pharmacol Biochem Behav 64: 337-345.

Conn PJ, Pin J (1997). Pharmacology and functions of metabotropic glutamate receptors. Annu Rev Pharmacol Toxicol 37: 205-237.
Dunn M, Killcross S (2006). Clozapine but not haloperidol treatment reverses sub-chronic phencyclidine-induced disruption of conditional discrimination performance. Behav Brain Res 175: 271-277.

Ebmeier KP, Lawrie SM, Blackwood DH, Johnstone EC, Goodwin GM (1995). Hypofrontality revisited: a high resolution single photon emission computed tomography study in schizophrenia. J Neurol Neurosurg Psychiatry 58: 452-456.

Fiorella D, Rabin RA, Winter JC (1995). The role of the 5- $\mathrm{HT}_{2 \mathrm{~A}}$ and $5-\mathrm{HT}_{2 \mathrm{C}}$ receptors in the stimulus effects of hallucinogenic drugs I: antagonist correlation analysis. Psychopharmacology 121: $347-356$.

Galici R, Echemendia NG, Rodriguez AL, Conn PJ (2005). A selective allosteric potentiator of metabotropic glutamate (mGlu) 2 receptors has effects similar to an orthosteric mGlu2/3 receptor agonist in mouse models predictive of antipsychotic activity. J Pharmacol Exp Ther 315: 1181-1187.

Gewirtz JC, Marek GJ (2000). Behavioral evidence for interactions between a hallucinogenic drug and group II metabotropic glutamate receptors. Neuropsychopharmacology 23: 569-576.

Glennon RA, Titeler M, McKenney JD (1984). Evidence for 5-HT2 involvement in the mechanism of action of hallucinogenic agents. Life Sci 35: 2505-2511.

Glennon RA, Young R, Rosecrans JA (1983). Antagonism of the effects of the hallucinogen DOM and the purported 5-HT agonist quipazine by 5-HT2 antagonists. Eur J Pharmacol 91: 189-196.

Gonzalez-Maeso J, Wiesstaub N, Zhou M, Chan P, Ivic L, Ang R et al (2007). Hallucinogens recruit specific cortical 5-HT(2A) receptor-mediated signaling pathways to affect behavior. Neuron 53: 439-452.

Gresch PJ, Barrett RJ, Sanders-Bush E, Smith RL (2007). Serotonin$2 \mathrm{~A}$ receptors in rat anterior cingulate cortex mediate the discriminative stimulus properties of lysergic acid diethylamide. J Pharmacol Exp Ther 320: 662-669.

Hermle L, Funfgeld M, Oepen G, Botsch H, Borchardt D, Gouzoulis E et al (1992). Mescaline-induced psychopathological, neuropsychological, and neurometabolic effects in normal subjects: experimental psychosis as a tool for psychiatric research. Biol Psychiatry 32: $976-991$.

Javitt D, Balla A, Burch S, Suckow R, Xie S, Sershen H (2004). Reversal of phencyclidine-induced dopaminergic dysregulation by N-methyl-D-aspartate receptor/glycine-site agonists. Neuropsychopharmacology 29: 300-307.

Kaplan RD, Szechtman H, Franco S, Szechtman B, Nahmias C, Garnett ES et al (1993). Three clinical syndromes of schizophrenia in untreated subjects: relation to brain glucose activity measured by positron emission tomography (PET). Schizophr Res 11: 47-54.

Klodzinska A, Bijak M, Tokarski K, Pilc A (2002). Group II mGlu receptor agonists inhibit behavioural and electrophysiological effects of DOI in mice. Pharmacol Biochem Behav 73: 327-332.

Krystal JH, Abi-Saab W, Perry E, D’Souza DC, Liu N, Gueorguieva $\mathrm{R}$ et al (2005). Preliminary evidence of attenuation of the disruptive effects of the NMDA glutamate receptor antagonist, ketamine, on working memory by pretreatment with the group II metabotropic glutamate receptor agonist, LY354740, in healthy human subjects. Psychopharmacology (Berl) 179: 303-309.

Lindahl J, Keifer J (2004). Glutamate receptor subunits are altered in forebrain and cerebellum in rats chronically exposed to the NMDA receptor antagonist phencyclidine. Neuropsychopharmacology 29: 2065-2073.

Lorrain D, Baccei C, Bristow L, Anderson J, Varney M (2003). Effects of ketamine and N-methyl-D-aspartate on glutamate and dopamine release in the rat prefrontal cortex: modulation by a group II selective metabotropic glutamate receptor agonist LY379268. Neuroscience 117: 697-706. 
Marek G, Wright R, Schoepp D (2006). 5-Hydroxytryptamine2A (5-HT2A) receptor regulation in rat prefrontal cortex: interaction of a phenethylamine hallucinogen and the metabotropic glutamate2/3 receptor agonist LY354740. Neurosci Lett 403: 256-260.

Marek GJ, Wright RA, Schoepp DD, Monn JA, Aghajanian GK (2000). Physiological antagonism between 5-hydroxytryptamine $2 \mathrm{~A}$ and group II metabotropic glutamate receptors in prefrontal cortex. J Pharmacol Exp Ther 292: 76-87.

Moghaddam B, Adams B (1998). Reversal of phencyclidine effects by a group II metabotropic glutamate receptor agonist in rats. Science 281: 1349-1352.

Muschamp JW, Regina MJ, Hull EM, Winter JC, Rabin RA (2004). Lysergic acid diethylamide and (-)-2,5-dimethoxy-4-methylamphetamine increase extracellular glutamate in rat prefrontal cortex. Brain Res 1023: 134-140.

Patil ST, Zhang L, Martenyi F, Lowe SL, Jackson KA, Andreev BV et al (2007). Activation of mGlu2/3 receptors as a new approach to treat schizophrenia: a randomized Phase 2 clinical trial. Nat Med 13: 1102-1107.

Pei Q, Tordera R, Sprakes M, Sharp T (2004). Glutamate receptor activation is involved in $5-\mathrm{HT}_{2}$ agonist-induced Arc gene expression in the rat cortex. Neuropharmacology 46: 331-339.

Rujescu D, Bender A, Keck M, Hartmann A, Ohl F, Raeder H et al (2006). A pharmacological model for psychosis based on $\mathrm{N}$ methyl-D-aspartate receptor hypofunction: Molecular, cellular, functional, and behavioral abnormalities. Biol Psychiatry 59: 721-729.

Schreiber R, Brocco M, Audinot V, Gobert A, Veiga S, Millan MJ (1995). (1-(2,5-dimethoxy-4 iodophenyl)-2-aminopropane)induced head-twitches in the rat are mediated by 5-hydroxytryptamine (5-HT) 2A receptors: modulation by novel 5-HT2A/2C antagonists, D1 antagonists and 5-HT1A agonists. J Pharmacol Exp Ther 273: 101-112.

Scruggs JL, Patel S, Bubser M, Deutch AY (2000). DOI-induced activation of the cortex: dependence on $5 \mathrm{HT}_{2 \mathrm{~A}}$ heteroreceptors on thalamocortical glutamatergic neurons. J Neurosci 20: 8846-8852.

Scruggs JL, Schmidt D, Deutch AY (2003). The hallucinogen 1-[2,5-dimethoxy-4-iodophenyl]-2-aminopropane (DOI) increases cortical extracellular glutamate levels in rats. Neurosci Lett 346: 137-140.
Smith RL, Barrett RJ, Sanders-Bush E (2003). Discriminative stimulus properties of 1-(2,5-dimethoxy-4-iodophenyl)-2aminopropane [(+/-)DOI] in C57BL/6J mice. Psychopharmacology (Berl) 166: 61-68.

Titeler M, Lyon R, Glennon R (1988). Radioligand binding evidence implicates the brain $5-\mathrm{HT}_{2}$ receptor as a site of action for LSD and phenylisopropylamine hallucinogens. Psychopharmacology 94: 213-216.

Vollenweider FX, Geyer MA (2001). A systems model of altered consciousness: integrating natural and drug-induced psychoses. Brain Res Bull 56: 495-507.

Vollenweider FX, Leenders KL, Scharfetter C, Antonini A, Maguire $\mathrm{P}$, Missimer J et al (1997a). Metabolic hyperfrontality and psychopathology in the ketamine model of psychosis using positron emission tomography (PET) and [18F]fluorodeoxyglucose (FDG). Eur Neuropsychopharmacol 7: 9-24.

Vollenweider FX, Leenders KL, Scharfetter C, Maguire P, Stadelmann O, Angst J (1997b). Positron emission tomography and fluorodeoxyglucose studies of metabolic hyperfrontality and psychopathology in the psilocybin model of psychosis. Neuropsychopharmacology 16: 357-372.

Vollenweider FX, Vollenweider-Scherpenhuyzen MFI, Babler A, Vogel H, Hell D (1998). Psilocybin induces schizoprenia-like psychosis in humans via a serotonin-2 agonist action. Neuroreport 9: 3897-3902.

Willins DL, Meltzer HY (1997). Direct injection of 5-HT2A receptor agonists into the medial prefrontal cortex produces a head-twitch response in rats. J Pharmacol Exp Ther 282: 699-706.

Winter JC, Eckler JR, Rabin RA (2004). Serotonergic/glutamatergic interactions: the effects of mGluR $2 / 3$ receptor ligands in rats trained with LSD and PCP as discriminative stimuli. Psychopharmacology 172: 233-240.

Winter JC, Kieres AK, Zimmerman MD, Reissig CJ, Eckler JR, Ullrich T et al (2005). The stimulus properties of LSD in C57BL/6 mice. Pharmacol Biochem Behav 81: 830-837.

Xi Z, Ramamoorthy S, Baker D, Shen H, Samuvel D, Kalivas P (2002). Modulation of group II metabotropic glutamate receptors signaling by chronic cocaine. J Pharmacol Exp Ther 303: 608-615.

Zhai Y, Carolyn GA, Zhai J, Nisenbaum ES, Johnson MP, Nisenbaum LK (2003). Group II metabotropic glutamate receptor modulation of DOI-induced c-fos mRNA and excitatory responses in the cerebral cortex. Neuropsychopharmacology 28: 45-52. 